\title{
Journeys beyond the West: World Orders and a 7 th century Buddhist Monk
}

\author{
L. H. M. LING*
}

\begin{abstract}
Novice Lee ('Frank') seeks world peace and thinks he has found it in the Liberal world order. He informs the Learned One, head of the monastery. Through their discussions, Frank discovers that the Liberal world order, despite its promises, offers neither 'democracy' nor 'peace'. Turning to the Confucian world order of 'all-under-heaven' (tianxia), they find it similarly top-down and one-way. Finally, Frank and the Learned One, now joined by their brother monks and sister nuns, consider the life of the 7 th century monk, Xuanzang. He inspires Frank to imagine a 'worldly world order' where humility and learning drive one's engagements with others, rather than what we have today: hegemony and imperialism.
\end{abstract}

L. H. M. Ling (PhD, MIT) is an Associate Professor in the Graduate Program in International Affairs (GPIA) at The New School in New York City. Her research agenda focuses on developing a post-Western, post-Westphalian understanding of and approach to International Relations/World Politics. Dr. Ling is the author of three books: Democratizing International Relations: Culture as Method (Routledge, forthcoming), Postcolonial International Relations: Conquest and Desire between Asia and the West (Palgrave Macmillan, 2002), and Transforming World Politics: From Empire to Multiple Worlds (Routledge, 2009), co-authored with Anna M. Agathangelou (York University). Additionally, Dr. Ling is developing a textbook, Learning World Politics: A Wanderer's Guide to Global Traditions, Volume I: Confucianism, Hinduism, Islam, for advanced undergraduates and entry-level graduate students. From 2008-2010, Dr. Ling was a Faculty Fellow with the India China Institute (ICI) at The New School. She is working on a manuscript with other ICI Fellows titled, Rethinking Borders and Security, India and China: New Connections for Ancient Geographies. Dr. Ling's articles have appeared in various journals and anthologies.

\section{Cast}

THE LEARNED ONE Head of the Monastery

NOVICE LEE/FRANK A New Recruit MONKS \& NUNS Members of the Monastery ELDERLY MONK Expert on Xuanzang

\footnotetext{
* I am grateful to Payal Banerjee, Martha Bonham, Stephen Chan, Boyu Chen, Erica Dingman, Gavan Duffy, Christopher Goto-Jones, Kathleen Maloney, Yumiko Mikanagi, Binod K. Mishra, Tim Pachirat, Patricia J. Robertson, Everita Silina, Tan Chung, Jishnu Shankar, and Hong Anh Thi $\mathrm{Vu}$, as well as two anonymous reviewers, for their contributions to this article. Nevertheless, I retain all responsibility for the contents herein. This article was first presented at the 'After Liberalism?' conference for Millennium: Journal of International Studies, London School of Economics, 17-18 October 2009.
} 


\section{Introduction}

Curtains rise. The stage is empty and dark except for a single shaft of light on a lone figure, a monk in saffron robes sitting crossed-legged on a prayer mat. It is the Learned One. ${ }^{1}$ A screen above the stage shows an image of a 'sea of clouds' at dawn, indicating we are high up in the Himalayas. All is quiet and peaceful. We hear crickets and chanting in the background.

Suddenly, an eager voice calls from Stage Right. Lights turn on. Enter Novice Lee, panting. He carries a heavy computer bag slung across a shoulder.

NOVICE LEE: Learned One, Learned One! I've found it!

LEARNED ONE (opening one eye): Found what, my child?

NOVICE LEE (still panting): The plan for world peace!

LEARNED ONE (returning to meditative pose, keeping both eyes closed): Remarkable. And where, may I ask, did you find it?

NOVICE LEE: On the Internet! It is truly the fount of all things. See, it gave me this document and for free!

(He waves a thick slab of paper.)

LEARNED ONE: Please, tell me more.

(The Learned One gives up trying to meditate and turns to the novice. He is a bright, earnest young man with great aptitude but little discipline so far. The Learned One likes him dearly and wishes him well, whatever he may choose for his future. Still too recent a recruit, Novice Lee is far from being ordained.)

NOVICE LEE: It's called 'The Princeton Project on National Security'. It's from that great university in America by the same name! ${ }^{2}$

LEARNED ONE (smiling slightly): I know Princeton. I spent some time there in my youth. (The novice's eyes widen with wonder.) Still, Novice Lee, how do you know this Project is important?

NOVICE LEE: The sponsors and authors of this Project are all famous and important people! ${ }^{3}$

LEARNED ONE: Ah. .

NOVICE LEE (pausing slightly): Before we continue, Learned One, may I beg an indulgence?

${ }^{1}$ This is a fictional title. I use it to convey the sense of respect usually accorded to the head of a monastery. In India, this person is called gurudeva ('immortal master'); in Tibet and Nepal, rinpoche ('incarnate'); in China, fa shi ('dharma teacher/master'); in Japan, jushoku ('resident minister'); in Vietnam, viện chủ ('institute owner'); in Thailand, luang paw ('grand' or 'royal father'). Although this person is typically a man, it is not always so. For this reason, I refrain from giving 'the Learned One' a specific gender identity.

${ }^{2}$ G. John Ikenberry and Anne-Marie Slaughter, Co-Directors, Forging A World of Liberty Under Law: US National Security in the 21st Century, Final Report of the Princeton Project on National Security (Princeton: Woodrow Wilson School of Public and International Affairs, 2006). Available at: $\{$ http://www.princeton.edu/ ppns/report.html $\}$ accessed on 13 September 2009.

${ }^{3}$ They include a former Secretary of State (George Shultz), former National Security Advisor (Anthony Lake), a Director of Policy Planning (Anne-Marie Slaughter) in the State Department under Hillary Clinton, and a Professor of Politics and International Affairs (G. John Ikenberry) at Princeton University. 
LEARNED ONE: Of course.

NOVICE LEE: Please call me by my new name, Frank.

LEARNED ONE: Frank?

NOVICE LEE/FRANK: Yes. I've decided to take a modern, outward-reaching name - to be more compatible with our times. This way, I could communicate with others more easily from across the valleys and over the seas. I found this name on the Internet also. It belonged to a famous American singer.

(Faint echoes of 'doo bee doo bee doo' in the background. Frank adds quickly -)

He's passed on so he wouldn't be offended by my using his name. (quietly and shyly) Music and song are good metaphors, I think, for my purpose.

LEARNED ONE: Why an American singer, if you don't mind?

FRANK: America and its culture seem most universal - that is, popular - in the world today. So I thought this name would be most useful.

LEARNED ONE: Very well, Novice Frank -

FRANK: Er, if you please, Learned One, just Frank will do.

LEARNED ONE: Frank, it is. Please tell me about the Princeton Project.

\section{Act I: The Princeton Project}

FRANK (enthusiastically): It says we need a Liberal world order.

LEARNED ONE: What does this mean?

FRANK: Democracy, individual liberty, and 'a framework of order established by law'.

LEARNED ONE: And its relation to world peace is ..?

FRANK: A set of fair and just rules for all.

LEARNED ONE: How does it work?

FRANK: A Concert of Democracies will ensure a Democratic Peace. ${ }^{5}$

LEARNED ONE: Democratic Peace?

FRANK: It's the idea that democracies don't fight one another. The German philosopher, Immanuel Kant, originated this notion of a 'perpetual peace' among like-minded republics. ${ }^{6}$

\footnotetext{
${ }^{4}$ Slaughter and Ikenberry, Forging A World of Liberty Under Law: US National Security in the 21st Century, p. 6.

5 '[The purpose of a "Concert of Democracies"] would be to [...] serve as the institutional embodiment and ratification of the "democratic peace", Ibid., p. 25.

${ }^{6}$ For a critical review of this literature, see Andreas Behnke, "Eternal Peace" as the Graveyard of the Political: A Critique of Kant's Zum Ewigen Frieden', Millennium: Journal of International Studies, $36: 3$ (2008), pp. 513-31.
} 


\section{LEARNED ONE: And the Concert of Democracies? ${ }^{7}$}

FRANK: These are states that measure up to PAR - that is, (reads) 'Popular, Accountable, and Rights-regarding, ${ }^{8}$ Clever, isn't it?

LEARNED ONE: Uh, yes ... How does the Project propose to bring every state up to PAR?

FRANK: Through linkages and networks. Connecting international institutions with domestic ones will spread Liberalism throughout the globe. ${ }^{9}$

And the economy plays an important role. Together, capitalism and democracy can 'manag[e] crises', 'provid[e] incentives], and 'enhance the power of attraction of the world of liberal democracies'. ${ }^{10}$

LEARNED ONE: Tell me, what does the Project say about culture?

FRANK (eagerly): Oh, it's in favour of it! The Project wants to promote 'liberty under law' in accordance with the different histories, cultures, and stages of development that exist in the world. This will prevent 'growing resentment, fear, and resistance'. ${ }^{11}$

LEARNED ONE: Even on military matters?

FRANK: On military matters ... (searches the text) ... the Project quotes former US Secretary of State, Henry Kissinger: ${ }^{12}$

[I]n many ways several geopolitical worlds coexist, with Western Europe and North

America in the 21st century, East Asia in the 19th, and the Middle East rooted in the 17th.

$\mathrm{Hmm} \ldots$

LEARNED ONE: Something wrong?

FRANK: This quote suggests that the West leads - or should lead - because it represents the Future. Everyone else is just catching up.

LEARNED ONE: Speaking of catching up, what about China? Does the Project mention it?

FRANK: Yes, it identifies China as one of the 'Major Threats and Challenges' to world order. ${ }^{13}$

7 '[It] would be selective, but self-selected. Members would have to pledge not to use or plan to use force against one another; commit to holding multiparty, free-and-fair elections at regular intervals; guarantee civil and political rights for their citizens enforceable by an independent judiciary; and accept the responsibility to protect.' Ibid., p. 7.

${ }^{8}$ Ibid., p. 6.

9 '[W]e need to build, or rebuild, not simply an international order but a liberal international order [... with] international institutions [...] integrally connected to the domestic conditions necessary for liberty under law [...]'. Ibid., p. 23.

${ }^{10}$ Ibid., p. 23.

11 Ibid., p. 19.

12 Ibid.

13 The full list includes: '(1) the collapse of order in the Middle East, (2) global terror networks, (3) the proliferation and transfer of nuclear weapons, (4) the rise of China and order in East Asia, (5) global pandemics, (6) energy, and (7) the need for a protective infrastructure within and around the US.' Ibid., p. 23. 
LEARNED ONE: Why?

FRANK (reads):

The rise of China is one of the seminal events of the early 21st century. America's goal should not be to block or contain China, but rather to help it achieve its legitimate ambitions within the current international order and to become a responsible stakeholder in Asian and international politics. ${ }^{14}$

LEARNED ONE: How kind of America to help. But is China an irresponsible stakeholder at present?

FRANK (laughing): O Learned One, I hope you don't mind my saying so, but you are most hilarious when you joke! Of course the Project wants China to be a responsible stakeholder in the Liberal world order.

LEARNED ONE: Nothing escapes you, I see! But, seriously, isn't China already part of the Liberal world order? How else did its economy grow so fast in recent years? ${ }^{15}$

FRANK: The Project probably sees it as economic integration, not political or cultural.

LEARNED ONE: Ah, so the Project distinguishes between these domains of activity?

FRANK: Yes and No. The Project fears that China will remain politically and culturally 'alien' despite increasing globalisation.

At the same time, the Project expects China to adjust to the West, given the 'soft power' of the US and other Liberal democracies. ${ }^{16}$

LEARNED ONE: What do you think of this proposition?

FRANK (ruminating): Sounds like a one-way street. First, the Project wants everybody to 'come up' to PAR.

Then, the Project wants to 'manage' China.

And, if force is necessary, so be it. ${ }^{17}$ The Project is quite open about keeping US military superiority, ${ }^{18}$ even pre-emptive war as an option! ${ }^{19}$

${ }^{14}$ Ibid., p. 9.

15 The Chinese government announced its economy grew by 8 per cent in 2009. See BBC News (22 October 2009), available at: $\{$ http://news.bbc.co.uk/2/hi/business/8319706.stm $\}$ accessed on 22 October 2009. The global economy, in contrast, is facing the 'worst crisis since the 1930s', BBC News (10 March 2009), $\{$ http://news.bbc.co.uk/2/hi/7934920.stm $\}$ accessed on 12 December 2009.

16 ' [...] Chinese officials and institutions [will have to] develop a degree of transparency and integrity comparable to the level of other participants in the network. Further, collective regulations and practices agreed on by network members will have to be enforceable through local administrative agencies or courts. Similar networks in areas such as securities regulation or antitrust enforcement routinely collect and disseminate best practices, which serve to transmit the values and practices of rights-regarding governments to other governments.' Ibid., p. 6.

17 '[B]uilding and maintaining a world of liberty under law requires a mix of sticks and carrots. Liberty requires order, and order, at some level, must be able to harness force.' Ibid., p. 20.

18 'The US should aim to sustain the military predominance of liberal democracies and encourage the development of military capabilities by like-minded democracies in a way that is consistent with their security interests.' Ibid., p. 31. 
LEARNED ONE: What about the Democratic Peace?

FRANK: Now I'm unsure how democratic or peaceful it is ... The Project offers no principles or guidance on what happens when systems mix. It presumes only that total conversion is both possible and desirable.

LEARNED ONE: Would conversion be so bad?

FRANK (agitatedly): For those outside the Concert, conversion means not perpetual peace but a perpetual pox!

This Liberal world order claims to protect and promote individual liberty through democracy. But, really, the Concert seeks to turn all those who do not measure up to PAR - and that covers a majority of the globe - into disciples, servants, and lackeys, at best, or ...

LEARNED ONE: Or ..?

FRANK: Rogues, revolutionaries, and terrorists, at worst! ${ }^{20}$ And sometimes, the former turns into the latter while the latter often remains yoked to the former.

LEARNED ONE: How do you mean?

FRANK: The Philippines, for example, was annexed by the US in 1899 and granted independence in 1946. From its very beginning, then, the Philippines has been tethered to America's interests and power in Asia. ${ }^{21}$ To secure this compliance, Washington's representatives allied with those in charge in Manila who are primarily Catholic and landowning - to isolate and marginalise 'rebel' groups like the Muslims or Moro people in Mindanao, a land rich in minerals and resources. The government in Manila now links the Moro to other terrorist groups like Al-Qaeda. ${ }^{22}$

So Manila's external servitude to Washington exacerbates and perpetuates an internal rebellion that justifies greater expenditures of blood and treasure to fight so-called terror, just so elites, in Washington and Manila alike, could claim they are working hard to preserve stability and prosperity for all. ${ }^{23}$

19 'As a matter of strategy, it is unhelpful either to rule the preventive use of force out completely or to identify it as the policy of choice.' Ibid., p. 8.

20 Pinar Bilgin and Adam D. Morton, 'Historicising Representations of "Failed States": Beyond the Cold War Annexation of the Social Sciences?', Third World Quarterly, 23:1 (2002), pp. 55-80; Samir Amin, The Liberal Virus: Permanent War and the Americanisation of the World (New York: Monthly Review Press, 2004).

${ }^{21}$ See, for example, Roxanne L. Doty, Imperial Encounters: The Politics of Representation in North-South Relations (Minneapolis: University of Minnesota Press, 1996).

22 Raymond Bonner, 'Philippine Camps Are Training Al Qaeda's Allies, Officials S', New York Times (31 May 2003), \{http://www.hvk.org/articles/0603/49.html accessed on 8 March 2010; Preeti Bhattacharii, 'Terrorism Havens: Philippines', Council on Foreign Relations, (updated 1 June 2009), \{http://www.cfr.org/publication/9365/\} accessed on 13 March 2010.

${ }^{23}$ For a critique of this rationale from a Muslim woman's perspective, see Amirah Ali Lidasan, 'Moro Women's Struggle for Human Rights in the Philippines', paper presented at the Regional Conference on Advancing Gender Equality and Women's Empowerment in Muslim Societies, (11-12 March 2009), Jakarta, Indonesia, sponsored by the UN Development for Women (UNIFEM), Canadian International Development Agency (CIDA). and International Center for Islam and Pluralism (ICIP). \{http://unifem-eseasia.org/docs/agewems/11.Amirah\%20Lidasan.pdf $\}$ accessed on 16 March 2010. 
LEARNED ONE: You have an excellent point, my child - er, Novice - Frank. Does your Liberal world order still seem like a good idea?

FRANK (sounding depressed): I'm beginning to wonder ...

LEARNED ONE: Doesn't this proposition sound familiar, though?

FRANK: Yes! Critics call it 'hegemony'.

LEARNED ONE: Is it a recent phenomenon?

FRANK: Today's hegemony, of course, was yesterday's 'white man's burden'. ${ }^{24}$ In both cases, the same group wants to be in charge.

LEARNED ONE: Is the West alone in perpetrating a top-down, one-way world order?

FRANK (eyes lighting up): Seems like the West and China have more in common than each realises. Are you referring, Learned One, to the Confucian world order of 'all under heaven' or tianxia? ${ }^{25}$

LEARNED ONE: Why do you think that, Frank?

FRANK: There are important distinctions, of course, but also striking similarities between the two!

LEARNED ONE: Intriguing. But first, how about some tea? Let's invite other members of our monastery to join in. They would have much to contribute, I'm sure.

(The Learned One rolls up his prayer mat. He and Frank leave Stage Left. We hear the monastery's bells ringing in the background. It is tea time.)

\section{Act II: Tianxia}

Curtains rise. We are in the monastery's spacious Hall of Meditation. The overhead screen shows a teapot with steam streaming out the spout. We hear the slurp and splash of tea drinking and pouring.

In the middle of the Hall is a 4' $\times$ 4' box of sand for meditative and illustrative purposes. The Learned One sits, cross-legged, on a large, flat cushion in saffron silk at one end of the sandbox. The rest of the monastery is similarly seated-monks on one side, nuns the otheraround the sandbox, on cotton cushions of brown, red, yellow, purple, and other colours. There are about twenty of them altogether.

Before each group of five is a long, low table of dark, lacquered teak. A large, earthen pot of steaming, fragrant tea centres each table, surrounded by tiny, round, ceramic cups. Also displayed are small bowls of nuts and fruit.

The Learned One addresses the gathering.

LEARNED ONE: Novice Lee - uh, Frank - and I are having the most interesting discussion: the Princeton Project, democratic peace, hegemony and

\footnotetext{
${ }^{24}$ See Chapter Four of Anna M. Agathangelou and L. H. M. Ling, Transforming World Politics: from Empire to Multiple Worlds (London: Routledge, 2009).

${ }^{25}$ Tianxia is pronounced 'tian-shia'.
} 
imperialism. We've come to a comparison between a Liberal world order and a Confucian one.

\section{(The gathering murmurs interest and approval.)}

Frank suggests that the Liberal and Confucian world orders are alike despite obvious differences in philosophy, time, and place. What say you?

NUN \#1 (inquiringly): How are they alike?

FRANK: Both offer a grand and unified vision of order for all peoples and societies. $^{26}$

MONK \#1 (loudly): Tianxia may have ruled as a concept for two millennia but it was never realised. And, in modern times, it hasn't even served as a concept. Why is it relevant for us today?

(This question seems a little too direct, too bellicose. Everyone steals a glance at Monk \#1. Perhaps he is suffering from indigestion or some other discomfort?)

FRANK: Actually, Brother Monk, that is not quite accurate.

Tianxia has always been an active concept in Confucian Asia. ${ }^{27}$ Even until the last world war, scholars and officials were debating it from Beijing to Hanoi, Singapore to Tokyo. ${ }^{28}$ And today, tianxia is regaining attention as the Chinese Communist Party (CCP) presents a related concept, a 'harmonious world', for international affairs. ${ }^{29}$

MONK \#1: Some say tianxia is just a rhetorical ploy by the Chinese government to resist US pressures to liberalise rather than an actual prescription for foreign policy. $^{30}$

FRANK: That may be true but who knows for sure? Moreover, this tactic makes tianxia more, not less, appealing. A scholar from China, for example, suggests

26 Tingyang Zhao, 'Rethinking Empire from a Chinese Concept “All-under-Heaven” (Tian-xia)', Social Identities, 12:1 (January 2006), pp. 29-41; Huang Yiehwei, 'Lun "tianxia weigong” sixiangde chuantong neihan yu xianshi yiyi' (On the Implicit and Practical Meanings of the tianxia Tradition), Chongqing gongxueyuanbao (Journal of Chongqing Institute of Technology, Social Science Edition), 21:8 (August 2007), pp. 196-8; Shih Chih-yu and Hsieh Ming-Shan, 'Xifang bu zai xibian: xifangzhuyide ziwuorenshi fangfa' (The West that is not Western: Self-Identification in the Oriental Modernity), Dongya yanjiu (Studies of East Asia), 39:2 (2008), pp. 1-32.

27 Throughout Japan's Tokugawa period (17-19th centuries), for example, various Confucian and neo-Confucian scholars debated what they called tenka, the Japanese version of tianxia. (I thank Chris Goto-Jones for this reminder. See also, Shih and Hsieh, 'Xifang bu zai xibian: xifangzhuyide ziwuorenshi fangfa', for how tenka differed from tianxia when filtered through Shintoism). In China, Sun Yatsen rallied republican forces against the dying Qing dynasty in 1911 with the slogan of 'justice under tianxia' (tianxia weigong).

${ }^{28}$ For example, Imperial Japan's proclamation of a Greater East Asia Co-Prosperity Sphere in 1940 combined elements of tianxia with European imperialism. \{http://www.worldfuturefund.org/wffmaster/ Reading/Japan/Japan-1940.htm $\}$ accessed on 26 January 2010.

${ }^{29}$ See, for example, Qing Cao, 'Confucian Vision of a New World Order? Culturalist Discourse, Foreign Policy and the Press in Contemporary China', The International Communication Gazette, 69:5 (2007), pp. 431-50; Jiang Xiyuan, 'Cong tianxiazhuyi dao hexie shijie: zhongguo waijiao zhexue xuanze jiqi shijian yiyi' (From Tianxiaism to a Harmonious World: The Significance of China's Choice in Foreign Relations Philosophy and Practice), Waijiao pinglun (Foreign Affairs Review), 97 (August 2007), pp. 46-53.

30 William A. Callahan, 'Chinese Visions of World Order: Post-Hegemonic or a New Hegemony?', International Studies Review, 10:4 (December 2008), pp. 749-61. 
that the CCP is in a better position than at any time in Chinese history to realise tianxia's goal of a harmonious world. ${ }^{31}$

MONK \#1 (gruffly): Still, what makes tianxia worthy of our attention?

(Monk \#l's neighbour pours him some tea, hoping that will help. The Learned One notices the gesture and bows slightly to the kind neighbour in acknowledgement.

Monk \#1 sees this exchange and senses he may have acted out of turn.)

NUN \#1: To answer this question, we must review what tianxia means.

FRANK: Quite right, Sister Nun! (whips out laptop) According to one, authoritative source, tianxia has three meanings: (1) 'the universe' or 'the world'; (2) the 'hearts of all peoples' or the 'general will of the people' and, (3) 'a world institution, or a universal system for the world, a utopia of the world-as-onefamily'. ${ }^{32}$ Altogether, these convey a sense of 'world-ness' under tianxia.

LEARNED ONE: Liberalism accounts for the Liberal world order. What is tianxia's organising ideology?

NUN \#2: Ren.

LEARNED ONE: Ah, what the Confucian classics refer to as 'humaneness' or 'sociality'? $?^{33}$

NUN \#2: Yes. My knowledge, of course, is incomplete. But please allow me to share what I know.

The Analects defines ren as the ability 'to love all men'. ${ }^{34}$ Ren is composed of two 'radicals' or roots. One refers to 'person'; the other, the number 'two'. Thus ren means, literally, a society of two or more persons.

(She writes the Chinese character for ren on the sandbox. It shows on the screen over the stage.)

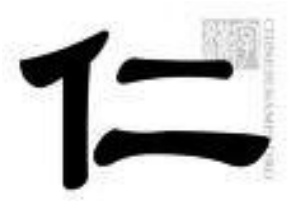

Hence, ren cannot conceive of anything - whether person, institution, society, or state - outside of community. One is necessarily and always enmeshed with others.

${ }^{31}$ Huang Yiehwei, 'Lun "tianxia weigong" sixiangde chuantong neihan yu xianshi yiyi' (On the Implicit and Practical Meanings of the tianxia Tradition).

32 Zhao, 'Rethinking Empire from a Chinese Concept “All-under-Heaven” (Tian-xia)'.

${ }^{33}$ Hwa Yol Jung, 'Confucianism and Existentialism: Intersubjectivity as the Way of Man', Philosophy and the Phenomenological Research, 30:2 (December 1969), pp. 193-4.

34 Analects quoted in Ibid., p. 191, emphasis in original. 
From ren comes a sense of multiplicity. The Grand Historian, Sima Qian, ${ }^{35}$ drew on what he called 'mutual illumination' to extract 'truth in plurality'. ${ }^{36} \mathrm{He}$ would record an assassin, for instance, as a 'romantic avenger' in one passage and 'bandit', in another. ${ }^{37}$ From their juxtaposition, it is suggested, we may get at the 'truth' of this character.

$\mathrm{Su}$ Shi, the famous Song Dynasty poet, put it another way. One could relate differently to the same object, he said, even if it is inanimate, depending on one's relationship to it (recites):

\section{Mornings I view Wu Mountain's breadth, Evenings I view its distant reach; \\ Wu Mountain assumes many appearances Turning about to pose for its lover. ${ }^{38}$}

Such is the extent of my knowledge of ren.

(Nun \#2 bows, lowering her eyes demurely.)

LEARNED ONE: Thank you, Sister Nun, for such a, ahem, learned exposition. (turning to general gathering) How is ren expressed or exercised?

MONK \#2: Through 'exemplary power' or $d e .{ }^{39}$ The Confucians believed that power comes from an ethical order, not just political institutions or military might.

FRANK: Sorry to interrupt but this concept of de, it seems to contrast completely with the notion of state power in the Liberal world order.

MONK \#2: That's right. De requires no fixities like borders or sovereignty or even a national body like a government to give it meaning.

Rather, de emanates from a leader's proper cultivation. This depends on how the leader relates to family, community, state, and the universe. The reverse applies as well: that is, how the universe, the state, the community, and the family relates to oneself. $^{40}$

The idea is that if a society's leader is able to set such an admirable standard of virtue, then the rest of society cannot help but follow.

Each element depends on the others. Each also determines the others. All contribute to de. That is tianxia.

${ }^{35}$ Sima Qian is pronounced 'sima chien'.

${ }^{36}$ Wai-Yee Li, 'The Idea of Authority in the Shih chi (Records of the Historian)', Harvard Journal of Asiatic Studies, 54:2 (December 1994), p. 395.

37 Ibid., p. 400.

${ }^{38}$ Ronald C. Egan, Word, Image, and Deed in the Life of Su Shi (Cambridge: Harvard University Press, 1994), p. 185.

${ }^{39} \mathrm{De}$ is pronounced 'duh'. I take this translation from James Anderson, The Rebel Den of Nùng Tri Cao: Loyalty and Identity Along the Sino-Vietnamese Frontier (Seattle: University of Washington Press, 2007), p. 15.

${ }^{40}$ For elaboration on this notion of Confucian interrelationality and world politics, see L. H. M. Ling, Postcolonial International Relations: Conquest and Desire between Asia and the West (London: Palgrave Macmillan, 2002). For a translation of the original text in the Great Learning (daxue), see James Legge, The Four Books (Taipei: Culture Book Co., 1992), pp. 2-7. 
LEARNED ONE: How does tianxia govern, then?

MONK \#3: As a world-family.

Tianxia calls for 'cherishing men from afar'. ${ }^{41}$ Typically, the Chinese Emperor, as the Son of Heaven and centre of the Confucian world order, would pacify 'barbarians' by offering a marital alliance between one of his sisters or concubines with a tribal chieftain. In this way, all become members of the Emperor's family, both literally and politically.

FRANK: What about the role of the economy?

MONK \#4: People must live well, that's all. ${ }^{42}$ This means having adequate food, clothing, and shelter. Moreso, the people should be able to enjoy their lives and not just trudge from one chore to another.

FRANK: And military matters?

MONK \#5: A good example comes from Sunzi's The Art of War. ${ }^{43}$ Many today mistake it for a Chinese version of Machiavelli's The Prince or a manual for cut-throat strategies in war or business.

These overlook Sunzi's own purpose, philosophy, and worldview. ${ }^{44}$ Sunzi preferred diplomacy, negotiations, and even deception over war. His perfect scenario was to win war without spilling blood or wasting treasure. But if war was inevitable, then he urged caution by minimising its costs.

Sunzi was not just being prudent or humane. He believed that opposites complemented each other, thereby producing the possibility of change at all times. Where there is hardness, for example, there is also softness; fixity, mobility; bravery, cowardliness; victory, defeat. ${ }^{45}$

Everything is subject to change. Nothing can be taken for granted.

LEARNED ONE: What about relations with others? What does tianxia propose in this regard?

MONK \#6: Transformation. ${ }^{46}$

LEARNED ONE: From what to what?

41 James L. Hevia, Cherishing Men from Afar: Qing Guest Ritual and the Macartney Embassy of 1793 (Durham: Duke University Press, 1995); Xue Jieling, 'Chunquiu bangjiao sixiang xulun' (Discussion of Texts on Thoughts about Diplomatic Relations during the Spring and Autumn Period), Qiushi xuekan (Seeking Truth), 30:1 (January 2003), pp. 106-10.

42 This was the fumin policy. See, for example, Huang Yiehwei, 'Lun "tianxia weigong” sixiangde chuantong neihan yu xianshi yiyi' (On the Implicit and Practical Meanings of the tianxia Tradition).

43 544-496 BCE.

${ }^{44}$ Ching-Chane Hwang and L. H. M. Ling, 'The Kitsch of War: Misappropriating Sun Tzu for an American Imperial Hypermasculinity', in Bina D'Costa and Katrina Lee-Koo (eds), Gender and Global Politics in the Asia Pacific (London: Palgrave Macmillan, 2009), pp. 59-76.

${ }^{45}$ Ping-ti Ho, Youguan sunzi laozi de sanpian kaocheng (Three Studies on Sun Tzu and Lao Tzu) (Taipei: Institute of Modern History, Academica Sinica, 2002).

46 This was the xianghua (pronounced 'shiang-hua') policy. See James L. Hevia, Cherishing Men from Afar: Qing Guest Ritual and the Macartney Embassy of 1793. 
MONK \#6: Foe to friend, stranger to family. It's the other side of 'cherishing men from afar'.

LEARNED ONE: Is this fundamentally different from the Liberal world order?

MONK \#6: Yes and No. The Liberal world order demands assimilation ('come up to PAR'); whereas, tianxia seeks transformation ('be my friend/family').

But they overlap in one area and that is the direction of change. Like the Liberal world order, transformation under tianxia is one-way only. It seeks always to turn the 'barbarian' toward the Confucian; the periphery, to the centre. But unlike the Liberal world order, Confucian transformation does not 'discipline' or 'reform' others should transformation fail to take place. They are seen, simply, as mired in barbarity. ${ }^{47}$

MONK \#1 (wishing to amend his previous bellicosity): Perhaps we could sum up the discussion so far.

Let us draw a comparison between the Liberal world order and tianxia. Everyone, please, help me with your suggestions.

(He begins drawing on the sandbox. Everyone pitches in. The final product looks like Figures 1 and 2. Everyone approves.)
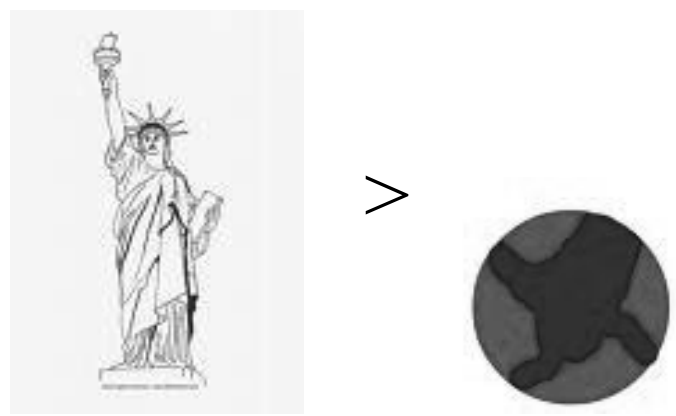

Figure 1. The Liberal world order.
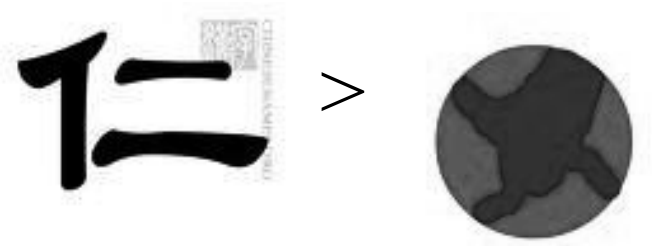

Figure 2. Tianzia.

${ }^{47}$ In this sense, Confucianism is a non-universalistic doctrine. Zhang Xiangiong, 'The Philosophical Feature of Confucianism and its Position in Inter-Cultural Dialogue: Universalism or NonUniversalism?', Frontiers in Philosophy from China, 4:4 (2009), pp. 483-92. 
LEARNED ONE: Given all this, could one conclude that Confucians and Liberals alike offer a world order of top-down, one-way power?

MONK \#7: One would have good reason to. Sunzi himself may have preferred peace over war, diplomacy over defence, and strategy over brute force but Chinese history is full of wars, conquests, killings, and enslavements. Sunzi himself lived in one of the bloodiest eras in Chinese history. ${ }^{48}$

But we need not rely on ancient times for evidence. Just look at Chinese policies toward our neighbours, the Tibetans ${ }^{49}$ - or the Uighurs, for that matter ${ }^{50}$ - and we get a sense of Confucian transformation in practical terms.

Moreover, the family serves as a poor model for world politics. We all know that families are capable of all kinds of abuses and humiliations, exploitations and vice. Even where abuses may not occur, patriarchy still defines the Confucian family. ${ }^{51}$ Where is ren in this case?

(The nuns nod approvingly. Their brother monks have come a long way.)

NUN \#3: Aren't China's current controversies with Tibetans and Uighurs as much a product of Liberalism as Confucianism? After all, why are the Tibetans agitating for 'sovereignty' and the Uighurs for 'civil rights'? ${ }^{52}$

MONK \#7: No doubt, Sister Nun. For this reason, many in Asia today seek to 'de-colonize', 'de-imperialize', and 'de-Cold War' the region. ${ }^{53}$

It's not that they are against 'sovereignty' or 'civil rights'. Rather, they want to define these concepts on their own terms from their own circumstances, rather than the West's. They ask: what is 'Asia' anyway?

${ }^{48}$ Sunzi's lifetime shaded from the Spring and Autumn period (722-481 BCE) to the Warring States period (475-221 BCE).

49 Wang Lixiong, Tianzang: Xizang the mingyun (The Destiny of Tibet) (Taipei: Locus Publishing, 2009).

50 Andrew Jacobs, 'China Fears Ethnic Strife Could Agitate Uighur Oasis', New York Times (22 July 2009), \{http://www.nytimes.com/2009/07/23/world/asia/23kashgar.html\} accessed 3 August 2009); Huma Yusuf, 'Effects of Uighur Unrest', Dawn.com (13 July 2009), \{http://www.dawn.com/wps/ $\mathrm{wcm} /$ connect/dawn-content-library/dawn/news/world/16-effects-of-uighur-unrest-hs-06\} accessed on 3 August 2009.

51 Timothy Brook and Hy V. Luong (eds), Culture and Economy: The Shaping of Capitalism in Eastern Asia (Ann Arbor: University of Michigan Press, 1997); Jongwoo Han and L. H. M. Ling, 'Authoritarianism in the Hypermasculinized State: Hybridity, Patriarchy, and Capitalism in Korea', International Studies Quarterly, 42:1 (March 1998), pp. 53-78; Thanh-Dam Truong, 'The Underbelly of the Tiger: Gender and the Demystification of the Asian Miracle', Review of International Political Economy, 6:2 (1999), pp. 133-65.

52 See, for example, 'Tibetan Sovereignty has a Long, Disputed History', National Public Radio (11 April 2008) $\{$ http://www.npr.org/templates/story/story.php?storyId=89552004 $\}$ and Rebiya Kadeer, 'A Civil Rights Movement for Uighurs', Guardian (14 July 2009), \{http://www.guardian.co.uk/ commentisfree/2009/jul/14/china-uighur-equality-xinjiang\} accessed on 15 March 2010.

${ }^{53}$ Chen Kuan-Hsing, Qudiguo: Yazhou zuowei fangfa (Towards De-Imperialization: Asia as Method) (Taipei: Flaneur Publisher, 2007).

${ }^{54}$ Sun Ge, 'How Does Asia Mean?' and Wang Hui, 'The Politics of Imagining Asia: A Genealogical Analysis', in Kuan-Hsing Chen and Chua Beng Huat (eds), The Inter-Asia Cultural Studies Reader (London: Routledge, 2007), pp. 9-65 and 66-102; Wang Yimen, 'Screening Asia: Passing, Performative Translation, and Reconfiguration', Positions: East Asia Cultures Critique, 15 (2007), pp. 319-43. 
In fact, the continent of Asia has always been dynamic, fluid, and multiple. The Silk Road, after all, mixed peoples, languages, cultures, and religions for fifteen centuries! $^{55}$

FRANK (despairingly): All this is very nice but what about world order? It seems we have decided that though the Liberal world order and tianxia may each have worthy elements, both remain hegemonic and imperialistic. Consequently, neither offers a sustainable order for the world.

LEARNED ONE: Is a world order necessary?

FRANK: We can't escape having one since globalisation entwines us all, for good or ill. And given the amount of suffering that passes for daily life in too many parts of the world today, is it not better to have a world order by design than by default? ${ }^{56}$

MONKS \& NUNS (chant): Emituofo! $!^{57}$

FRANK: What to do, Learned One? How should one proceed?

LEARNED ONE: What if, as the Silk Road reminds us, we were to turn to our own long and venerable traditions for inspiration and insight?

MONK \#8 (slapping his knee): Excellent idea, Learned One! After all, our monastery stands in testament to one who has given us a legacy of worlds and how to find order within them.

FRANK (curiously): Who is that?

MONK \#8 (laughingly): Why the 7th century monk, Xuanzang, ${ }^{58}$ of course!

FRANK: You mean the monk who was immortalised in the 16th century Chinese classic, Journey to the West?

MONK \#8 (nodding): In those days, 'the West' meant India. Today, our Prior Brother Monk is remembered throughout the Buddhist world. ${ }^{59}$

FRANK (admiringly): Well ...!

LEARNED ONE: We have arrived at a momentous juncture in our discussion. I'm sure we'll progress with greater vigour after our noonday repast, prayers, and daily chores. Shall we?

(The Learned One rises. Everyone repairs to the Dining Hall.)

55 The Silk Road lasted from 1 BCE-14 AD. See, for example, Susan Whitfield, Life Along the Silk Road (Berkeley: University of California Press, 1999) and D. Devahuti, Ancient Central-Asia and India (New Delhi: Oxford University Press, 2002).

56 See, for example, the Human Development Report (2009), http://hdr.undp.org/en/media/HDR_2009_ EN_Summary.pdf $\}$ accessed on 12 October 2009.

57 This utterance means a 'sigh' or 'purification' in response to a horrifying violation of taboos and norms. Emituofo is the sinicised version of Amitābha, the Buddha of infinite qualities. Tan Chung and Geng Yingzeng, 'India and China: Twenty Centuries of Civilizational Interaction and Vibrations', D. P. Chattopadhyaya (General Editor), History of Science, Philosophy, and Culture in Indian Civilization, Vol. III, Part 6 (New Delhi: Centre for Studies in Civilizations, 2005), p. 62.

58 Xuanzang is pronounced 'shuan-tsang'.

${ }^{59}$ In Japan, for example, the monk is known as Genjō-sanzō (it also signifies a title given to a learned and devoted monk); in Korea, as Hyeon Jang; in Vietnam, people call him Đuròng Tăng, although official texts refer to him as Huyền Trang (many thanks to Hong Anh Thu Vi for this information); and in India, he is known as Hiuen Tsang. 


\section{Act III: Xuanzang's worlds}

Curtains rise. We are back in the Hall of Meditation. Lighting is muted to show it is late afternoon, a time for rest and tea. Everyone is seated as before. The screen overhead shows an image of the monk, Xuanzang.

LEARNED ONE: To continue with this morning's discussion, I have asked our resident archivist and temple historian to tell us about our Prior Brother Monk, Xuanzang.

(The Learned One motions to an elderly monk. He rises to narrate the history of Xuanzang, which he knows by heart.)

ELDERLY MONK (in a sing-song voice): ${ }^{60}$

In the year $629 \mathrm{AD}$, a young monk by the name of Xuanzang stole out in the middle of night to embark on his travels. The Tang Emperor Taizong, an unbeliever at the time, had expressly forbidden anyone to venture into what was known then as the 'western regions'. But Xuanzang was determined. Dissatisfied with the confusing and vague nature of Chinese translations of the sutras, he was determined to journey to India to learn from the source and bring back better knowledge to his homeland.

It took him 16 years. He trekked 10,000 miles from China to India, and back again, across mountains and deserts, jungles and rivers, in the heat and the cold, through thirst and hunger, robbery and assault. More than once, Xuanzang faced mortal danger. But he persevered, never losing sight of his purpose or vision. (Emituofo!)

By the time of his death, Xuanzang had left a legacy of brilliance to last all time. It ranged from the archaeological ${ }^{61}$ to the anthropological ${ }^{62}$ to the $\operatorname{artistic}^{63}$ to the religious ${ }^{64}$ to the literary ${ }^{65}$ to his original motivation: that is, translation of over 1,000 scrolls. $^{66}$

We know of these deeds, events, and accomplishments from Xuanzang's own journals, fastidiously kept despite the hardships of his travels, and later remembrances by his disciples.

(The elderly monk bows upon finishing and sits down.)

LEARNED ONE: We are most grateful for your recitation, Senior Brother Monk. What would you say was Xuangzang's motivation for undertaking what he did?

${ }^{60}$ This passage is drawn from Sally Hovey Wriggins, The Silk Road Journey with Xuanzang (Boulder: Westview Press, 2004).

${ }^{61}$ For example: locations of principal Buddhist cities and monuments.

${ }^{62}$ For example: documentation of life in the oases, sacred cities like Bamiyan, quasi census of monks and monasteries in India and Central Asia.

${ }^{63}$ For example: Buddhist paintings, sculptures, statues, architecture like stupas, monasteries, the Asoka pillar at Sarnath, collection of Gupta images that so affected Tang art.

${ }^{64}$ For example: records of Buddhist beliefs, practices, iconography, pantheon, and legends.

${ }^{65}$ For example: the Monkey King, a Chinese counterpart to India's Hanuman.

66 These include the Heart Sutra, Diamond Sutra, Thirty Verses, Treatise on the Stages of Yoga Practice, and Master of Lapis Lazuli Radiance Tathagatha. 
ELDERLY MONK: Perhaps 'co-dependent arising' or pratītyasamutpāda. ${ }^{67}$ It teaches that our sense of who we are arises from reverberations with others. These lead to insight and connections where previously ignorance and divisions reigned. From this basis, we may begin to share in something larger than ourselves and approach that infinite ideal of love and compassion.

Such becoming involves the heart, not just the mind; and it requires a journey inside as much as outside. That is: through others, we may discover 'the genius that is already there'. ${ }^{6}$

Our brother monk, Thich Nhat Hanh, puts it pithily:

A teacher cannot give you the truth. The truth is already in you. You only need to open yourself - body, mind, and heart - so that his or her teachings will penetrate your own seeds of understanding and enlightenment. ${ }^{69}$

FRANK (excitedly): In other words, emancipation or enlightenment comes from two, simultaneous processes: (1) an internal interrogation of one's anger, fears, or prejudices that shackle us and, (2) an external engagement of discourse and disputation, care and mindfulness, with all forms of life, including Nature.

(The other monks and nuns look at Frank, thinking: Doesn't he know this already?)

ELDERLY MONK (patiently): This is called the process of 'interbeing' ${ }^{70}$ Once on this journey, we may aspire to the transcendent condition of 'no-mind'.

'No-mind' does not mean a mental emptiness but a spiritual fullness. It emerges when one lets go of false cravings, desires, and anxieties. Only then, could one be more responsive to the world.

Let me illustrate with another poem from Su Shi. He drew on the image of a 'thousand arms and eyes' to describe the condition of 'no-mind' (recites):

If a single person had a thousand minds,

They would fight with each other inside him,

What time would he have to respond to things?

But when a thousand arms have no single mind,

Every arm attains its proper place.

I bow to the Revered One of Great Compassion,

Desiring also to save all living beings.

May each actualize the way of no-mind

And each acquire a thousand arms and eyes. ${ }^{71}$

To allow a 'thousand arms and eyes' each to attain its 'proper place' does not mean retreating into a discrete insularity. Rather, this image suggests that when one is freed of false fears and desires -

${ }^{67}$ Similarities also exist between pratītyasamutpāda, ren, and the ancient Greek concept of poisies. Agathangelou and Ling, Transforming World Politics.

${ }^{68}$ I am grateful to Patricia Robertson for these words.

69 Thich Nhat Hanh, The Heart of the Buddha's Teaching (New York: Broadway Books, 1998), pp. 12-13. I am grateful to Jishnu Shankar for this reference.

${ }^{70}$ See, for example, Thich Nhat Hanh, Interbeing (Berkeley: Parallax Press, 1998).

${ }^{71} \mathrm{Su}$ quoted in Egan, Word, Image, and Deed in the life of Su Shi, p. 151. 
FRANK (impishly): Like a 'clash of civilizations' ${ }^{72}$

ELDERLY MONK (calmly continuing): - each 'arm' and 'eye' can find its own path to contentment. This is much-needed since the 'thousand arms and eyes' all come from and depend on one body - just like us, the peoples and societies of this Earth.

FRANK (slowly): So ... a 'thousand arms and eyes' convey another kind of democracy, doesn't it? Unlike the Liberal understanding of freedom, independence, and autonomy, which is based on an individual's struggles against or despite others, a 'thousand arms and eyes' tell us we can achieve the same in harmony with others. That is, if we remain respectful of and responsive to one another.

ELDERLY MONK: This is no abstract goal. It requires an active working through of conflicts and contradictions by recognising their underlying connections and complements. This is the genius within.

Equally important, a 'thousand arms and eyes' exhort us to recognise the other side of democracy and that is complicity. None of us is innocent of power or what makes it possible. ${ }^{73}$ For this reason, we are always responsible for our thoughts and actions - even our non-thoughts and non-actions.

FRANK: What about social and political institutions? Don't they hold us accountable as members of a society?

ELDERLY MONK: Yes and No. It mattered little to Xuanzang whether he was dealing with the state, the temple, the ashram, or the household. Each had its role yet was limited on its own. Rather, Xuanzang sought integration as a happy reconciliation of difference, as demonstrated by his journeys, discourses, debates, translations, and documentations.

In other words, society as a whole needs to value accountability in its institutions for them to have credibility with individuals, and for individuals to own this sense of accountability in order to demand it of their institutions. ${ }^{74}$ Otherwise -

FRANK: Even democracies could turn fascist, like Nazi Germany in the $1930 \mathrm{~s} !^{75}$

LEARNED ONE: What about the economy? What role does it play?

ELDERLY MONK: As a matter of belief, Xuanzang treated the material world as an illusion. For daily survival, however, he depended on the generosity of

72 Samuel P. Huntington, 'The Clash of Civilizations?', Foreign Affairs, 72:3 (1993), pp. 22-49.

${ }^{73}$ For an elaboration of how complicity worked in colonial power relations, see Ashis Nandy, The Intimate Enemy: The Psychology of Colonialism (Delhi: Oxford, 1988). For how complicity can be theorised into a model of 'multiple worlds', see Agathangelou and Ling, Transforming World Politics.

74 See, for example, Nidhi Srinivas, 'Gender Rights and Women's Leadership: The Right to Information Act in India', paper presented at a conference on 'Gender, Peace, and Security', hosted by the Gender Policy Working Group, School of International and Public Affairs (SIPA), co-sponsored by UNICEF/UNIFEM, Gender Policy Program, Economic and Political Development Concentration, CUPID, GLIPA the Conflict Resolution Working Group, Center for International Conflict Resolution, Columbia University, New York (23 October 2009).

75 William Allen, Nazi Seizure of Power: The Experience of a Single German Town, 1922-1945 (Danbury, CT: Franklin Watts, 1984). 
others since he only possessed the pilgrim's 'triple jewels' of a frugal robe, a walking stick, and a begging bowl. ${ }^{76}$

Nonetheless, our Prior Brother Monk exercised independence and autonomy, innovation and self-possession. Xuanzang not only defied the Tang Emperor's orders but also engaged in passionate debates and disputations with many kings and gurus during his travels, including the almighty King Harshavardhan of northern India and the Tang Emperor Taizong himself.

Ultimately, it was humility and a thirst for knowledge that impelled the Monk. He wanted to learn and engage, not to preach or convert or transform.

NUN \#2 (pipes up): I believe India's poet laureate, Rabindranath Tagore, captured this spirit in his poem, 'To the Buddha'. It reads, in part (recites):

O Serene, O Free, in thine immeasurable mercy and goodness wipe away all dark stains of the heart of this earth.

Thou giver of immortal gifts, give us the power of renunciation, and claim from us our pride. ${ }^{77}$

FRANK (moved): Beautiful ... Xuanzang may have come closer to what both the Confucians and the Liberals desire but cannot attain: that is, a worldly world order.

(Everyone is stunned.)

\section{Act IV: a worldy world order}

NUN \#3 (curiously): 'Worldly'? How could it be so for one whose life and work removed him from the world?

FRANK: I mean worldly in the sense that, like a 'thousand arms and eyes', multiple worlds make us who we are. ${ }^{78} \mathrm{~A}$ 'bandit', after all, can also be a 'romantic avenger'!

By recognising such worldliness, our judgments, prejudices, and hostilities begin to thaw. The dazzle and fear of a 'thousand arms and eyes', each fighting against the other, fade in comparison to the underlying connections that bind them so that we perceive, finally, their refuge in a common, single body.

LEARNED ONE: What would your worldly world order look like?

${ }^{76}$ Tan and Geng, Twenty Centuries of Civilizational Interaction and Vibrations, p. 76.

77 Rabindranath Tagore, Poems, ed. Krishna Kripalani (Calcutta: Visva-Bharati, 2003), pp. 129-130 (poem \#88). Many thanks to Tan Chung for this reference, and Binod K. Mishra and Uma Dasgupta for helping me find the Bengali version of it.

${ }^{78}$ Ling, Postcolonial International Relations, and Agathangelou and Ling, Transforming World Politics. 
FRANK (turning to Monk \#1): Brother Monk, if you wouldn't mind drawing another figure for us?

(Monk \#1 is only too happy to oblige.)

This is purely a thought experiment. But our Xuanzang-inspired, worldly world order would look something like this.

(Monk \#1 produces Figure 3 under Frank's instructions. Everyone 'Aahs!')

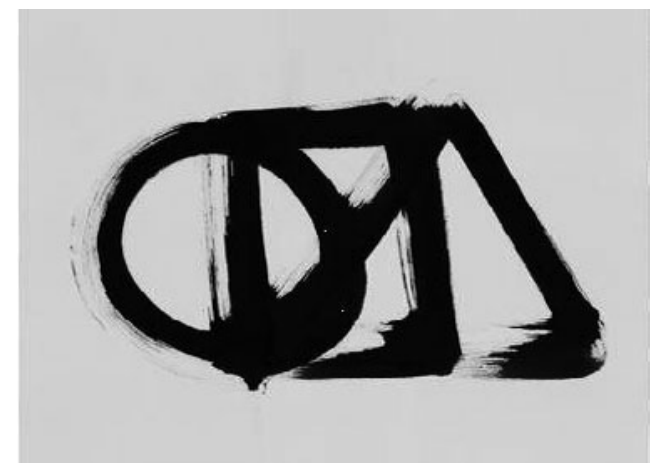

Figure 3. A worldly world order. ${ }^{79}$

LEARNED ONE: Could you elaborate, please?

FRANK: Certainly.

Linking the circle, square, and triangle signifies pratītyasamutpāda. No matter how different we think our worlds may be - like a circle to a square to a triangle each world comes into being from interactions with other worlds. We see this happening precisely where they intersect or overlap, ${ }^{80}$ bringing challenges as well as benefits - sometimes with one producing the other.

For example, our multiple worlds could lock into one another through patriarchy or some other hooks of power. ${ }^{81}$ This may enable multiple worlds to function smoothly but it also allows oppression.

${ }^{79}$ Painting by Sengai Gibon (1750-1838) titled, 'Universe'. \{http://www.raisethehammer.org/static/ images/sengai.jpg\} accessed on 18 January 2010.

${ }^{80}$ For examples of such cultural co-productions, see Martin Bernal, Black Athena: the Afroasiatic Roots of Classical Civilisation (The Fabrication of Ancient Greece 1765-1985, Volume 1) (New Jersey: Rutgers University Press, 1987); Paul Gilroy, The Black Atlantic: Modernity and DoubleConsciousness (Cambridge: Harvard University Press, 1993); Arturo Escobar, Encountering Development: The Making and Unmaking of the Third World (Princeton: Princeton University Press, 1996); John Hobson, The Eastern Origins of Western Civilisation (Cambridge: Cambridge University Press, 2004); Pinar Bilgin, 'The International Political "Sociology of a not so International Discipline", International Political Sociology, 3:3 (2009), pp. 338-42; Geeta Chowdhry and Shirin Rai, 'Geographies of Exclusion and the Politics of Inclusion: Race-Based Exclusions in the Teaching of International Relations', International Studies Perspectives, 10:1 (2009), pp. 84-91.

${ }^{81}$ See, for example, Bina D'Costa and Katrina Lee-Koo (eds), Gender and Global Politics in the Asia Pacific (London: Palgrave Macmillan, 2009). 
Other times, our multiple worlds may conflict. This could lead to wars, rebellions, 'regime change', and other sources of violence. But, at another level, differences among multiple worlds can also keep each world honest about itself as well as others, enabling all to evolve over time.

For instance, Confucian ren can help to cosmopolitanise Liberal governance. Who gets to set these 'fair' and 'just' rules for all, anyway? ${ }^{82}$

Similarly, Liberalism can help to dislodge tianxia's complacency. Notions of 'democracy', 'individual liberty', and 'a framework of order established by law' would compel transformation on all sides, not just one.

The concept of 'no-mind' guides us here. It urges mutual respect within and among all worlds. This does not mean non-interference so tyrants could do what they will with impunity. What 'no-mind' encourages, instead, is being responsive to others, not telling them what to do or how to think, but learning from them just as they can learn from us.

LEARNED ONE: What enables such communication across worlds, Frank? Where does the common vocabulary of inter-civilisational discourse come from? (Frank hesitates. He has not anticipated this question.)

Nun \#4 (intercedes): Everyday living. ${ }^{83}$ Much is made of the difficulties of multiple worlds to talk to one another. The presumption is that different norms, power, and interests, especially when embedded in contending worldviews, cannot reconcile or even meet. This is the 'clash of civilizations' perspective. Yet people cross such borders all the time, whether it is to survive colonialism, imperialism, and other forms of hegemony, or because it is fun and they're curious. ${ }^{84}$ And the locus of such border crossings can range from the mundane (food, dress, shelter, trade) to the sublime (music, art, religion). ${ }^{85}$ Indeed, Xuanzang wouldn't have been able to accomplish all that he did had he not crossed all sorts of borders. (Frank bows gratefully to Nun \#4. She nods back with a smile.)

LEARNED ONE: So we've been looking at all the wrong places for inter-civilisational dialogue?

FRANK: Yes and No. We need to look at discourse but we've set our sights too high when evidence lies right beneath our noses.

NUN \#5: 'Exemplary power' takes on a new meaning, in this case. It comes from 'the layperson' as much as 'the expert', 'local knowledge' as much as 'scientific

82 See, for example, Brooke A. Ackerly, 'Is Liberalism the Only Way toward Democracy? Confucianism and Democracy', Political Theory, 33:4 (August 2005), pp. 547-76.

${ }^{83}$ See, for example, John M. Hobson and Leonard Seabrooke (eds), Everyday Politics of the World Economy (Cambridge: Cambridge University Press, 2007) and Oliver P. Richmond, A Post-Liberal Peace (forthcoming).

${ }^{84}$ For a sample of this literature, see Geeta Chowdhry and L. H. M. Ling, 'Race(ing) Feminist International Relations: A Critical Overview of Postcolonial Feminism in International Relations', in Robert A. Denemark (ed.), The International Studies Encyclopedia (London: Blackwell Publishing, 2010), pp. 6038-57.

${ }^{85}$ See, for example, M.I. Franklin, Resounding International Relations: On Music, Culture, and Politics (London: Palgrave Macmillan, 2005); Roland Bleiker, Aesthetics and World Politics (London: Palgrave Macmillan, 2009). 
discoveries', 'tradition' as much as 'modernity'. ${ }^{86}$ Each relates to the others. Each determines the others. All contribute to a worldly world order.

FRANK: That's right, Sister Nun. Strict adherence to certain principles or ideology cannot determine how we organise ourselves. We could choose to borrow PAR elements or not, a family structure or not. Or aspects of each! Such formalities matter little so long as we are able to improve society's responsiveness to its people, and the people to one another. ${ }^{87}$

NUN \#6: This is an example of the 'other kind of democracy' that Brother Frank mentioned earlier. (Frank beams.) In recognising that everyone - Liberals and Confucians, men and women, masters and servants - has a role in producing us, we realise there is no need to assimilate or convert anyone. A world order or world-ness is already in place!

LEARNED ONE: What about practical matters like the economy?

FRANK: Xuanzang showed that these are as much social and spiritual as material. ${ }^{88}$ Most important is that ordinary folks are able to live well and without undue stress or grind. Because nothing stays the same and reversals are always imminent, cooperation can, does, and must coexist with competition. ${ }^{89} \mathrm{~A}$ 'zero-sum' attitude, in other words, does not work nor is it necessary. It merely jeopardises all forms of sentient life, including the Earth itself.

LEARNED ONE: Does this apply to military affairs as well?

FRANK: Definitely. It's not enough to wage a humane war as Sunzi recommended. Citizens need to speak up, also, across national boundaries and to one another..$^{90}$ Too often, dissent stops at the water's edge due to concerns about 'national security' when it has long been internationalised. ${ }^{91}$ We need to shatter

${ }^{86}$ For an articulation of this perspective in environmental terms, see Vandana Shiva, 'Reductionist Science as Epistemological Violence', in Ashis Nandy (ed.), Science, Hegemony and Violence: $A$ Requiem for Modernity, 4th edition (Tokyo: UN University, 1996), pp. 232-56.

${ }^{87}$ Note, for example, the generational nature of precedential learning with regard to capitalism and the Westphalian inter-state system in Asia. See Ling, Postcolonial International Relations.

${ }^{88}$ Agathangelou and Ling refer to this as 'relational materialism'. Agathangelou and Ling, Transforming World Politics.

89 The notion of 'cooperative competition' is not new, especially in the development of what is known as 'Asian capitalism'. See Ling, Postcolonial International Relations. For applications of 'cooperative competition' in other contexts, see John Rawls, A Theory of Justice (Cambridge: Harvard University Press, 1970); Charles Sabel and Michael Piore, The Second Industrial Divide: Possibilities for Prosperity (New York: Basic Books, 1984); and Amartya Sen, 'Gender and Cooperative Conflicts', in Irene Tinker (ed.), Persistent Inequalities: Women and Development (Oxford: Oxford University Press, 1990), pp. 123-49.

90 There is an increasing recognition of this need for inter-civilisational dialogue in world politics. In 1998, the UN (UN) named 2001 as the 'UN Year of Dialogue among Civilizations'. Despite the attacks on New York and Washington, DC on September 11 of that year, other nations have taken up the banner. Under the auspices of the UN and supported by the EU and the Vatican, first Spain then Turkey formed an 'Alliance of Civilizations' to enhance exchanges between 'Islam' and 'the West'. See, also, Fred Dallmayr and Abbas Manoochehri (eds), Civilizational Dialogue and Political Thought: Tehran Papers (New York: Lexington Books, 2007); Peter J. Katzenstein (ed.), Civilizations in World Politics: Plural and Pluralist Perspectives (London: Routledge 2009); Arlene Tickner and Ole Wæver (eds), International Relations Scholarship Around the World: Worlding Beyond the West (London: Routledge, 2009); Takashi Shogimen and Cary J. Nederman (eds), Western Political Thought in Dialogue with Asia (Lanham: Lexington Books, 2009).

91 Anna M. Agathangelou and L. H. M. Ling, 'Power, Borders, Security, Wealth: Lessons of Violence and Desire from September 11', International Studies Quarterly, 48:3 (September 2004), pp. 517-38. 
the illusion that what happens inside one set of borders has nothing or little to do with others elsewhere. ${ }^{92}$

LEARNED ONE: These are admirable principles, Frank, but do they have any practical import?

FRANK: Yes. Take terrorism, for example. Current policies tend to drive terrorism underground for they seek only to annihilate, subordinate, or conquer. ${ }^{93}$ With a worldly world order in mind, we ask: how can we convince an ideologue not to kill innocents, especially children, for a political ideal?

NUN \#7: Here, we can draw on the concept of 'interbeing' mentioned earlier, where a simultaneous process of internal interrogation supported by external engagement could help emancipate terror from the terrorist, ideology from the ideologue.

FRANK: And by 'terrorist' and 'ideologue', we mean those who decide the fate of others in fancy offices as well as barren caves. As for 'we', that refers to all of us including victims, bystanders, and the so-called removed or uninvolved.

(Some monks and nuns exchange sheepish glances.)

Such intervention requires input from inside and below, outside and above. Here, Xuanzang teaches us most directly. Like him, we need to learn about one another collectively and mutually, for extended periods of time, and through local institutions.

LEARNED ONE: How could we follow in his footsteps today?

FRANK (paces back and forth, rubbing his chin, then snaps his fingers): Mobile centres of learning! Instead of scholars, practitioners, and students gathering in one centre to study the world - which is the current model - they could journey from one location to another. And I don't mean short-term, student exchanges or government commissions to gather 'data' about 'others'. Our mobile centres of learning would be premised on mutual learning, in the localities, and for sustained durations. ${ }^{94}$ With such, we may continue Xuanzang's tradition of nurturing future 'worldizers'.

NUN \#8: What about the Internet? Doesn't it already 'worldize' us without the need for physical travel?

FRANK: The Internet is useful for many things but it can't replace actual, personal contact. We must see, smell, touch, hear, eat, drink, and discourse with a locality to know it.

92 Tarak Barkawi and Mark Laffey, 'The Postcolonial Moment in Security Studies', Review of International Studies, 32:4 (2006), pp. 329-52.

${ }^{93}$ For one example, see Petra Bartosiewicz, 'The Intelligence Factory: How America Makes its Enemies Disappear', Harper's Magazine (November 2009), \{http://harpers.org/archive/2009/11/0082719\} accessed on 17 December 2009. I thank Everita Silina for this reference. For a deeper analysis of why such strategies are taken, see Sankaran Krishna, Globalization and Postcolonialism: Hegemony and Resistance in the Twenty-First Century (Lanham: Rowman \& Littlefield.)

94 For one attempt at this model of learning, see: $\{$ http://ici.parsons.edu/institutions/india-china-institute/\}. 
This acknowledgement leads us to relate to others, as Xuanzang did, with humility and a thirst for learning. From power and wealth, we may begin to shift to a worldly world order of knowledge and sustainability that, over time, could culminate into love and compassion. And like Xuanzang, we embark on this journey knowing, all the while, that we may never, ever reach its shores.

MONKS \& NUNS (chant): Emituofo!

\section{Act V: Conclusion}

Curtains rise. The screen overhead shows a pagoda in moonlit shadow. Lighting is muted. Off-stage, we hear the monastery's bells ringing again, signalling time for the evening meal and prayers. We also hear plates of food being put on tables. The stage is empty except for Frank and the Learned One.

FRANK: I've learned much today, Learned One. Thank you. (He bows.)

LEARNED ONE: Not at all, Frank. I've learned a lot, too. Isn't that the point?

FRANK (nodding): Yes ... Um, Learned One, I've come to another decision. I'm keeping my old name.

LEARNED ONE: You're giving up Frank?

FRANK: Oh no. I will keep Frank for communication with those from across the valleys and over the seas. But I will remain Novice Lee here, especially with my brother monks and sister nuns.

LEARNED ONE: Why, Fr - uh, Novice Lee?

NOVICE LEE/FRANK: Well, as we have learned from Xuanzang, there's no need to be absolute, is there?

Moreover, I cherish the friendships that make me Novice Lee with all of you here, just as I'm sure I'll value the friendships that will make me Frank with others elsewhere. In fact, I think we should all have many names in many languages so we could have many friendships! You know what Shakespeare said -

LEARNED ONE (smiling): Yes, yes. Roses and names smelling sweet and all that. ${ }^{95}$ Excellent, my child.

(The Learned One turns to go.)

NOVICE LEE/FRANK (keeping pace): Uh, Learned One, just one more thing, if you don't mind. I can't help but notice that throughout our discussions, you asked questions only. Why is that?

95 The line comes from Romeo and Juliet (1594): 'What's in a name? That which we call a rose/By any other name would smell as sweet' (II.2). 
LEARNED ONE (eyes twinkling): How do you think I got to be the Learned One? ${ }^{96}$

(Lights out. Curtains down. Collective chanting of 'Om!' fills the theatre.)

\section{THE END}

${ }^{96}$ On the role and significance of asking questions in International Relations, see L. H. M. Ling, 'The Fish and the Turtle: Multiple Worlds as Method', in Michael Brecher and Fred Harvey (eds), Critical Perspectives in International Studies (Ann Arbor: University of Michigan Press, 2002), pp. $141-7$. 